\title{
Interleukins \& Fetal Fibronectin Levels In Preterm Delivery
}

\author{
Ragab H. EL-Yamani* and Maha G. Soliman** \\ * Obstetric and Gynecology Dept. Faculty of Medicine, Al-Margab University, Great Socialist \\ People's Libyan Jamahiriya and ** Pharmacology Dept (Medical microbiology and \\ immunology unit) Notional Organization for Drug Control and Research
}

\begin{abstract}
Although the prevention of preterm birth remains the most important challenge in obstetrics, the mechanism for the onset of preterm labor has not been fully explained. The purpose of the present study is to investigate the usefulness of cervicovaginal fetal fibronectin and certain cytokines (interleukin-1B and interleukin-8) levels during pregnancy as markers of preterm and term delivery. This study was performed on 130 pregnant women at 24 to 29 years old age. The women were classified into group I (women not in labor, $n=65$ ) and group II (women with spontaneous labor, $\mathrm{n}=65$ ). Each group was classified into two subgroups [preterm delivery ( $<37$ weeks gestation, $n=40)$ and full term delivery ( $>37$ weeks gestation, $n=25)$ ]. We obtained cervicovaginal swabs for fetal fibronectin and cervicovaginal fluids for cytokines determination.

The present study revealed that fetal fibronectin, IL- 1B and IL-8 levels were significantly higher in patients in preterm labor than in patients at preterm not in labor. They were significantly higher in women at full term in labor than in women at full term not in labor.

Interleukin- $\mathrm{BB}$ and IL-8 obtained from women not in labor increased exponentially as gestational age increased, and the cytokines levels were significantly correlated. This study revealed that cervicovaginal measurement of fetal fibronectin, IL-1B and IL-8 in combination with clinical findings may be useful for the evaluation of patients with threatened premature delivery.
\end{abstract}

\section{Introduction}

Preterm birth is probably the most challenge problem in modern medicine (Malak et al., 1996). Although preterm delivery (prior to 37 completed weeks of gestation) occurs only in $7 \%$ to $11 \%$ of births, they account for about $85 \%$ of neonatal deaths of normally formed infants (Creasy, 1993; Copper et al., 1993). In addition to the increased risk of neonatal morbidity, many of survivors will be permanently handicapped or disabled (Taylor, 1984). Despite significant advances in prenatal medicine, the incidence of preterm delivery has remained unchanged and stills a serious obstetric problem (Chien et al., 1997).

The diagnosis of early preterm labor is difficult and is accompanied by a high false positive rate. These false diagnosis result in unnecessary and potentially hazardous treatment for thousands of women annually (Gibbs et al., 1992 and Iams et al., 1995). Part of the clinical problem arises from the absence of objective criteria for the prediction or early diagnosis of preterm delivery. Unfortunately, the initial promise shown by risk scoring systems including a history of previous preterm delivery or abortion, uterine anomalies, heavy work, low socioeconomic status and cervical incompetence has been limited by its poor predictive value and its populations specific analysis and predicts at best $50 \%$ of preterm deliveries (Creasy and Merkatz 1990; Keirse, 1995). Cervical examination, screening for reduced breathing movements on ultrasound scanning or screening for recurrent uterine contractions provides little additional predictive power (Lockwood, 


\section{Interleukins \& Fetal Fibronectin..........}

1994; Morrison et al., 1996). An improved method of early diagnosis would be a significant advance (Iams et al., 1995; Burrus et al., 1995). Recently, attention has focused on the use of biochemical markers to identify women at risk for preterm delivery (Wennerholm et al., 1997).

The development of biochemical markers to permit the rapid and specific identification of high-risk patients would therefore be desirable. Among the family of glycoproteins found in plasma and extracellular fluid, fetal fibronectin appears to be a good candidate (Wiqvist 1993; Lockwood 1994; Lu et al 2001 ). It has primarily been identified in amniotic fluid, trophoblastic tissue and the extracellular matrix of decidua basalis (Langer et al., 1997). Feinberg et al. (1991), found that fetal fibronectin immunohistochemical staining was more intense in the extracellular matrix in areas of placental attachment, more specifically, where anchoring trophoblasts are located. This glycoprotien is detectable in cervicovaginal fluid during normal pregnancy at less than 21 weeks of gestation and at full term (Feinberg et al., 1991). However, the presence of fetal fibronectin in the cervices or vagina after twenty weeks is abnormal (Lockwood et al., 1991; Langer et al., 1997) and may indicate mechanical or inflammatory mediated disruption of the choriodecidual interface and provides a possible marker for risk of preterm labor (Leeson et al., 1996; Ness et al., 1998).

Full term and preterm labor share a common terminal pathway that includes increased uterine contractility, cervical ripening and membrane decidual activation associated with cervical dilatation and effacement (Gomez et al., 1994). Cervical ripening is an active process that involves marked changes in the connective tissue of cervix (Uldbjerg et al., 1983). It is characterized by the degradation of collagen (Rajabi et al., 1988), mediated by the enzyme collagenase and elastase. The activities of these proteases are increased during parturition (Tanaka et al., 1998). Infiltration of neutrophils in the cervix, which may be caused by cytokines or chemotactic factors in the cervix (El-Maradny et al., 1994, 1995), are the main source of collagenase and elastase during parturition (Osmers et al., 1992). Interleukin-lB (IL-I B), a 17-kd glycoprotein synthesized mainly by monocytes and macrophages (Dinarello 1991, 1996), is produced in the cervix and stimulate the tissue production of collagenase and elastase (Uchiyama et al., 1992). Interleukin-8 (IL-8), an 8-kd glycoprotein, is a chemotacting and activating factor for neutrophils (Baggiloilni et al., 1989). The cervix produces IL -8 and its production is enhanced by IL-1B (Barclay et al., 1993). Cervical ripening is considered a physiologic inflammatory process in which IL-I B and IL-8 play an essential role (El- Maradny et al., 1995;Franz et al., 2001). Although elevated cytokine levels in amniotic fluid are sensitive indicators of infection-associated preterm labor (Trautman et al 1992; Steinborn et al., 1996, 1998), the pathophysiologic roles of cervicovaginal levels of IL-1B and IL-8 in preterm labor and parturition have not been clarified.

The relationship of the combined presence of fetal fibronectin, IL- IB and IL8 in cervicovaginal secretions in pregnant women has not been assessed fully. The aim of this study was to investigate the reliability of the detection of these biochemical markers in the cervicovaginal secretions as predictors of preterm delivery.

\section{Subjects And Methods}

This study was conducted at AlZahraa hospital, Al- Azhar university and included 142 patients with singleton pregnancies between 24 and 41 weeks of gestation and intact membranes. Gestational age was calculated by date of last menstrual period and confirmed by ultrasonography done before 18 weeks of gestation.

Twelve patients included premature rupture of the membranes, oligohydramnios, congenital fetal anomalies, placenta previa, evident cervical bleeding, intrauterine growth restriction and microbial infections with the following examinations were excluded.

The participants (130 women) were classified into two groups, women not in labor (group I, $\mathrm{n}=65$ ) and women in 
spontaneous labor (group II, $n=65$ ). Samples obtained from the women not in labor were classified into two subgroups, preterm less than 37 weeks' of gestation (group $\mathrm{A}, \mathrm{n}=40$ ) and full term more than 37 weeks' of gestation (group $\mathrm{B}, \mathrm{n}=25$ ). Samples collected from women in spontaneous labor were also classified as preterm (group $\mathrm{C}, \mathrm{n}=40$ ) and full term (group D, $\mathrm{n}=25$ ).

After consent informed was obtained, each subject was examined with a vaginal speculum to collect specimens for microbial study, fetal fibronectin, IL-1B and IL-8. Digital examination of the cervix was then performed to assess cervical dilatation and effacement. All the patients who were admitted because of symptoms suggestive of preterm labor showed uterine contraction at a rate of 4 per 20 or 8 per 60 minuets, cervical effacement of $>80 \%$ and cervical dilatation equal to or not more $2 \mathrm{~cm}$. Preterm labor was defined by the tocolytic index score and diagnosed if the tocolytic index score was $>1$ and the patients required tocolysis.

\section{Sampling and biochemical assays:}

Cervical infection with Neisseria gonorrhoeae was evaluated by culture after plating on chocolate agar and Chlamydia trachomatis was evaluated by enzymelinked immunoassay. Trichomonas vaginalis and Candida albicans were identified either by microscopic examination of cervical discharge diluted with saline solution or by culture. Aerobic organisms and group B streptococci were identified by standard biochemical tests after plating on 5\% sheep blood agar, chocolate agar and MacConkey's agar plates (Tanaka et al 1998., Adair et al 1998).

Fetal fibronectin was determined quantitatively with an enzyme linked immuneosorbent assay (Fetal Fibronectin Enzyme Immunoassay; Adeza Biomedical, Snnyvale, California, USA) using monoclonal antibody FDC-6. The sample was taken with a sterile polyester swab from the commercially available collection kits. The swab was rolled gently in the posterior vaginal fornix and the cervix for 5-10 seconds, avoiding bloody areas when possible and extracted in $750 u \mathrm{~L}$ of the provided buffer solution. The sample was then stored at $-80^{\circ} \mathrm{C}$ until assay (Morrison et al., 1993). The absorbency of the samples and standards was then determined in duplicate by use of an automated microtiter plate reader. Absolute fetal fibronectin concentrations were obtained and recorded in micrograms per milliliter and a value of $>0.05 \mathrm{ug} / \mathrm{ml}$ was considered as positive (Lockwood et al., 1991).

Specimens for IL-1B and IL-8 were assayed with enzyme-linked immuonosorbent assays (ELISA) (Quantidne, R\&D, Minneapolis, Minn. USA). For this assay, sterile saline solution $(3 \mathrm{ml})$ was instilled in the posterior vaginal fornix with a 5-ml plastic syringe and was subsequently aspirated from the posterior fornix with the same syringe (Anai et al ., 1997). The amount of the fluid retrieved was $3.5 \pm 0.2$ $\mathrm{ml}(\mathrm{n}=22)$, the specimens were immediately centrifuged at $1800 \mathrm{~g}$ for 5 minutes at room temperature and stored at $80^{\circ} \mathrm{C}$ until assay of cytokines. For this assay the interassay coefficients of variation were $43 \%$ to $72 \%$ and $7.4 \%$ to $12.4 \%$ for IL-1 B and IL-8, respectively.

All results were expressed as mean \pm $\mathrm{SE}$, and a $\mathrm{P}$ value $<0.001$ was considered statistically significant, the cervical dilatation, was determined by simple regression analysis. The data were analyzed with student's $t$ test for parametric data and person correlation techniques where appropriate, $\mathrm{P}<0.001$ was considered significant.

\section{Results}

The results of the present work could be summarized in the next two tables and five figures.

The concentrations of IL-1B was significantly higher in women in preterm labor $(104.5 \pm 4.76 \mathrm{pg} / \mathrm{ml})$ than in women at preterm not in labor $(24.55 \pm 1.90 \mathrm{pg} / \mathrm{ml})$ and was significantly higher in women at full term in labor than in women at full term

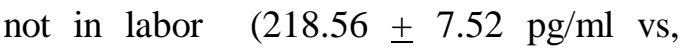
$127.20 \pm 7.36 \mathrm{pg} / \mathrm{ml}$ ) respectively, Table (1) .fig (1). 
IL-8 concentration was also significantly higher in women in preterm labor $(2273.85 \pm 57.22 \mathrm{pg} / \mathrm{ml})$ than in women at preterm not in labor $(503.875$ $\pm 22.75 \mathrm{pg} / \mathrm{ml}$ ) and was significantly higher in women at full term in labor than in women at full term not in labor $(5087.68 \pm$ $398.491 \mathrm{pg} / \mathrm{ml} \mathrm{vs}, 2575.76 \pm 79.79 \mathrm{pg} / \mathrm{ml})$ Table (1) fig (2).

There was a significant correlation between the IL-1B, IL-8 levels and the degree of cervical dilatation among women at term in labor $(\mathrm{n}=40, \mathrm{r}=0.492, \mathrm{p}<.002)$ and $(\mathrm{n}=40, \mathrm{r}=0.708, \mathrm{p}<.001)$ respectively Table (1) \& Fig (3), (4).

Cytokine IL-1B and IL-8 concentrations increased exponentially as the gestational age increased in women not in labor $(n=65, r=0.728$ for IL-1B at $\mathrm{p}<0.001$; and, $\mathrm{r}=0.695$ for IL-8, $\mathrm{p}<0.001$, Figs 3 and 4). Concentrations of IL-1B and IL- 8 were significantly correlated $(n=65, r=0.898$, $\mathrm{p}<0$.001), Fig ( 5).
There was also a significant correlation between the cytokines and gestational age in spontaneous labor group $(r=0.825$ for $\mathrm{IL}-1 \mathrm{~B}$, at $\mathrm{p} \leq 0.001)$ fig 6 and $(\mathrm{r}=0.553$ for IL-8 at $\mathrm{p} \leq 0.001$ ) fig 7 . Regarding the correlation between IL-1B and IL-8 in this group, there was a significant correlation fig (8).

All patients who in spontaneous labor were delivered their babies after 1 to 2 days from sampling. Among fetal fibronectin positive patients who delivered preterm, the mean concentration was $0.300 \pm 0.008$ $\mu \mathrm{g} / \mathrm{ml}$ compared with $0.421 \pm 0.017 \mu \mathrm{g} / \mathrm{ml}$ in women who delivered at full term (table 1). Fetal fibronectin values were significantly higher in full term and preterm women in spontaneous labor than in women not in labor (both full term and preterm), (fig 9).

At the cut-off $0.05 \mu \mathrm{g} / \mathrm{ml}$ of fetal fibronectin, it has a specificity of $90.71 \%$ and a sensitivity of $87.6 \%$, positive predictive value of $90.4 \%$ and the negative predictive value of $88.0 \%$ table (2).

Tab.(1): The descriptive statistics and the significance of IL-1B( pg/ml), IL-8 (pg/ml) and Fibronectin $(\mu \mathrm{g} / \mathrm{ml})$ in the four studied subgroups.

\begin{tabular}{|c|c|c|c|c|c|c|c|c|c|c|c|c|}
\hline & \multicolumn{4}{|c|}{ IL-1B (pg/ml) } & \multicolumn{4}{|c|}{ IL-8 (pg/ml) } & \multicolumn{4}{|c|}{ Fibronectin $(\mu \mathrm{g} / \mathrm{ml})$} \\
\hline & \multicolumn{2}{|c|}{ Not in Labor } & \multicolumn{2}{|c|}{ Spontaneous Delivery } & \multicolumn{2}{|c|}{ Not in Labor } & \multicolumn{2}{|c|}{ Spontaneous Delivery } & \multicolumn{2}{|c|}{ Not in Labor } & \multicolumn{2}{|c|}{ Spontaneous Delivery } \\
\hline & Pre term & Full term & Pre term & Full term & Pre term & Full term & Pre term & Full term & $\begin{array}{c}\text { Pre } \\
\text { term }\end{array}$ & Full term & Pre term & Full term \\
\hline Mean & 24.550 & 127.200 & 104.500 & 218.560 & 503.875 & 2575.760 & 2273.850 & 5087.680 & 0.055 & 0.057 & 0.300 & 0.420 \\
\hline S.E & 1.905 & 7.369 & 4.760 & 7.527 & 22.750 & 79.799 & 57.229 & 398.491 & 0.001 & 0.005 & 0.008 & 0.017 \\
\hline Median & 21.500 & 127.000 & 107.000 & 214.000 & 549.000 & 2671.000 & 2240.500 & 5764.000 & 0.055 & 0.054 & 0.305 & 0.439 \\
\hline S.D. & 12.051 & 36.844 & 30.103 & 37.634 & 143.884 & 398.993 & 361.947 & 1992.454 & 0.004 & 0.027 & 0.051 & 0.085 \\
\hline Rang & 51.000 & 140.000 & 110.000 & 148.000 & 553.000 & 1150.000 & 1528.000 & 6555.000 & 0.013 & 0.101 & 0.224 & 0.317 \\
\hline Minimum & 9.000 & 58.000 & 42.000 & 149.000 & 228.000 & 2019.000 & 1450.000 & 226.000 & 0.049 & 0.014 & 0.204 & 0.204 \\
\hline Maximum & 60.000 & 198.000 & 152.000 & 297.000 & 781.000 & 3169.000 & 2978.000 & 6781.000 & 0.062 & 0.115 & 0.428 & 0.521 \\
\hline Sum & 982.000 & 3180.000 & 4180.000 & 5464.000 & 20155.000 & 64394.000 & 90954.000 & 127192.000 & 2.205 & 1.413 & 11.985 & 10.506 \\
\hline Count & 40 & 25 & 40 & 25 & 40 & 25 & 40 & 25 & 40 & 25 & 40 & 25 \\
\hline $\begin{array}{lr}\text { Sig. } & \text { From } \\
\text { Not } & \text { in } \\
\text { Labor } & \\
\end{array}$ & & Increase & Increase & Increase & & Increase & Increase & Increase & & Decrease & Increase & Increase \\
\hline Pre term & & $P \leq 0.001$ & $P \leq 0.001$ & $P \leq 0.001$ & & $P \leq 0.001$ & $P \leq 0.001$ & $\mathrm{P} \leq 0.001$ & & NS & $P \leq 0.001$ & $P \leq 0.001$ \\
\hline t value & & 13.487 & 15.594 & 24.987 & & 24.969 & 28.740 & 11.484 & & 0.399 & 30.333 & 21.466 \\
\hline $\begin{array}{lr}\text { Sig. } & \text { From } \\
\text { Not } & \text { in } \\
\text { labor } & \end{array}$ & & & Decrease & Increase & & & Decrese & Increase & & & Increase & Increase \\
\hline Full term & & & $P \leq 0.001$ & $P \leq 0.001$ & & & $P \leq 0.005$ & $P \leq 0.001$ & & & $P \leq 0.001$ & $P \leq 0.001$ \\
\hline t value & & & 2.588 & 8.673 & & & 3.074 & 6.181 & & & 25.134 & 20.400 \\
\hline $\begin{array}{l}\text { Sig. From } \\
\text { Spontan- } \\
\text { eous } \\
\text { Dellivery }\end{array}$ & & & & Increase & & & & Increase & & & & Increase \\
\hline Pre term & & & & $P \leq 0.001$ & & & & $P \leq 0.001$ & & & & $P \leq 0.001$ \\
\hline T-value & & & & 12.808 & & & & 6.990 & & & & 6.414 \\
\hline
\end{tabular}




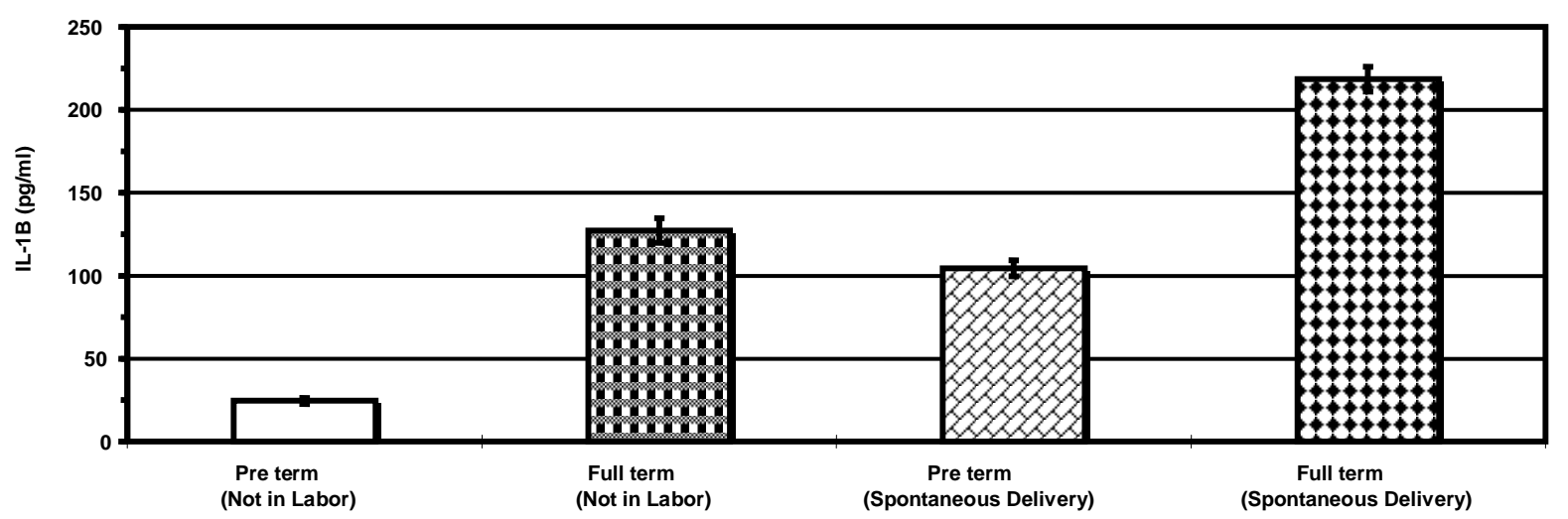

Fig. ( 1) : Changes in IL- 1B (pg/ml) in the four studied subgroups (mean + S.E.).

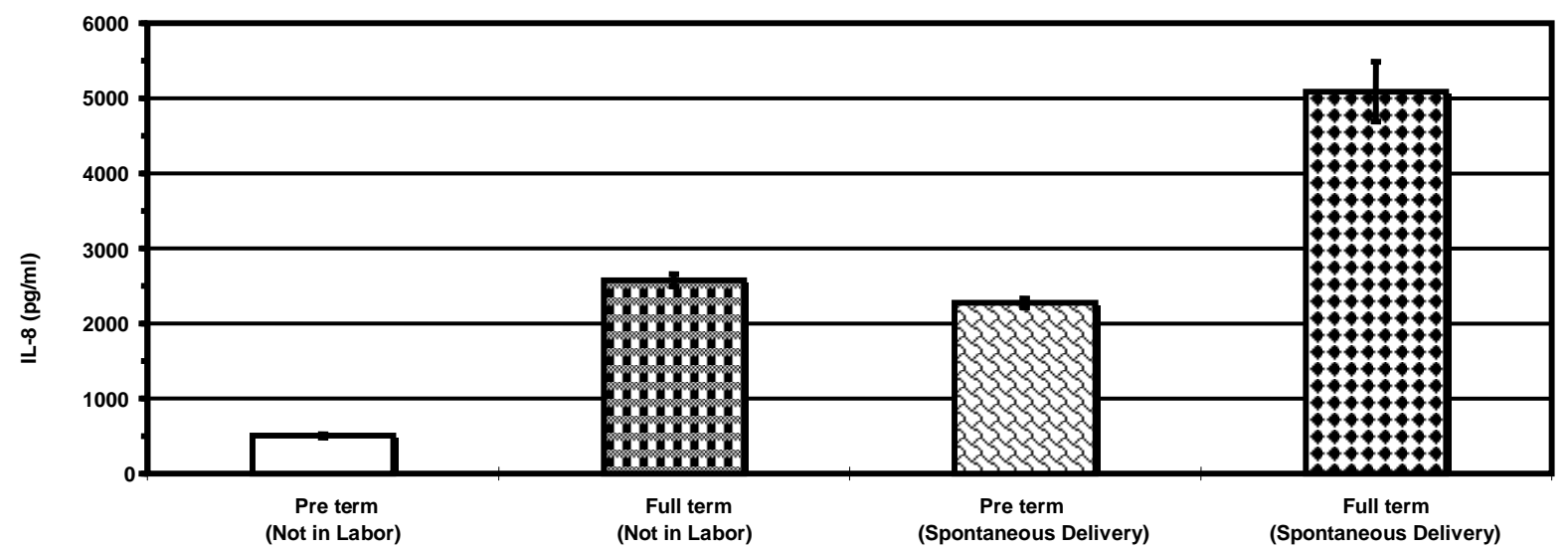

Fig. ( 2) : Changes in IL- $8(\mathrm{pg} / \mathrm{ml})$ in the four studied subgroups (mean \pm S.E.). 


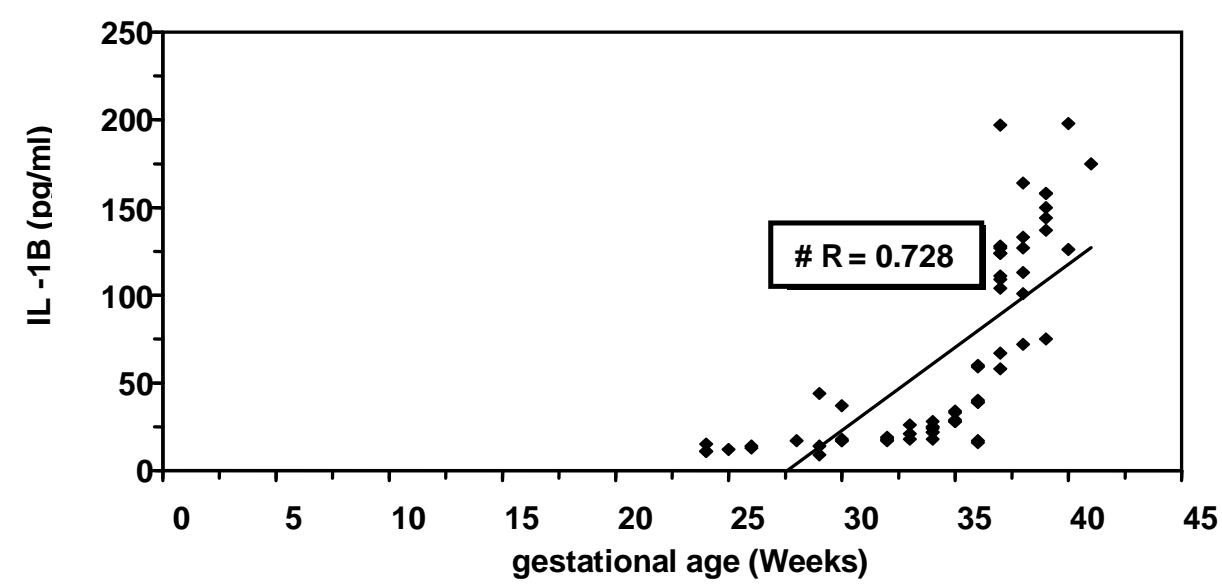

Fig. ( 3 ) : The correlation between IL1 B and gestational age in Not in labor Group.

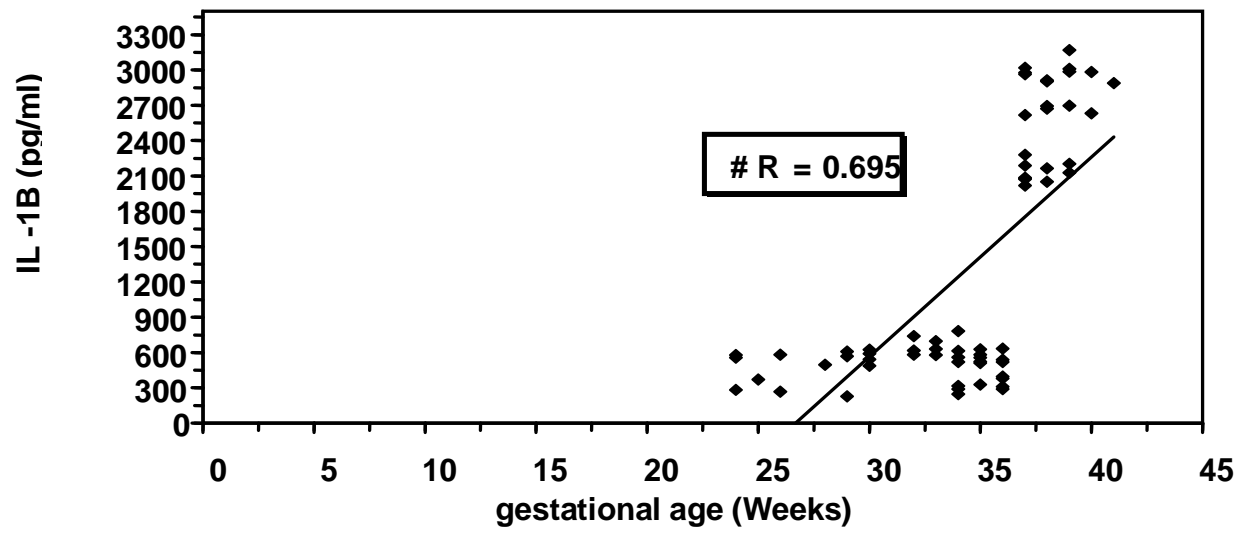

Fig. ( 4 ) : The correlation between IL- 8 and gestational age in Not in labor Group.

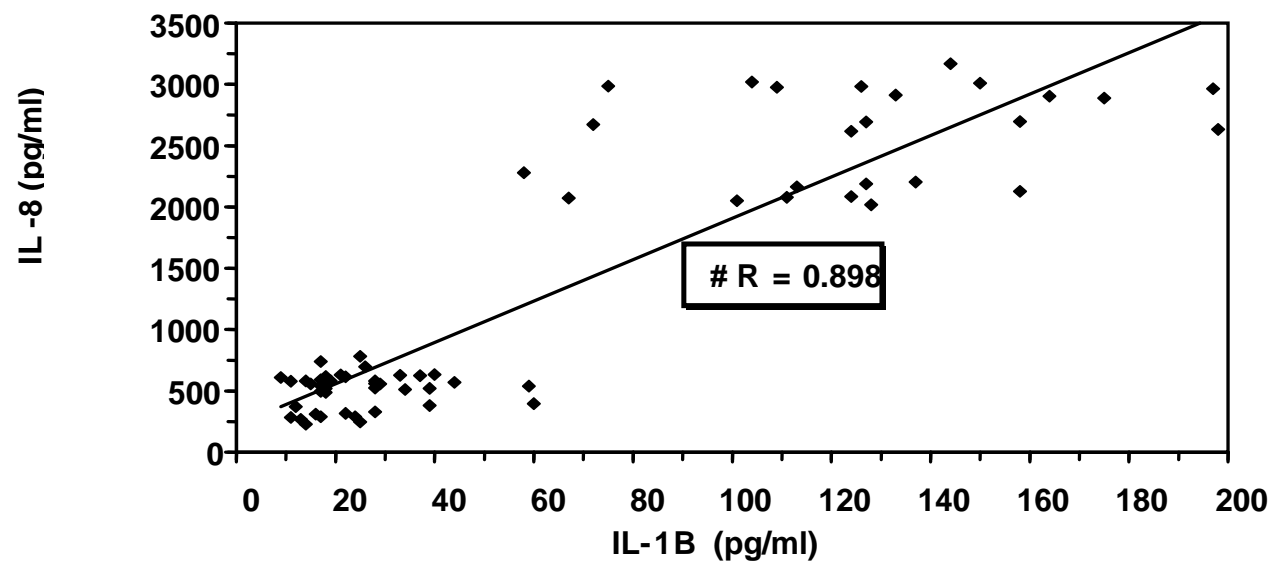

Fig. ( 5 ) : The correlation between IL- 1 B and IL- 8 in Not in Labor Group. 


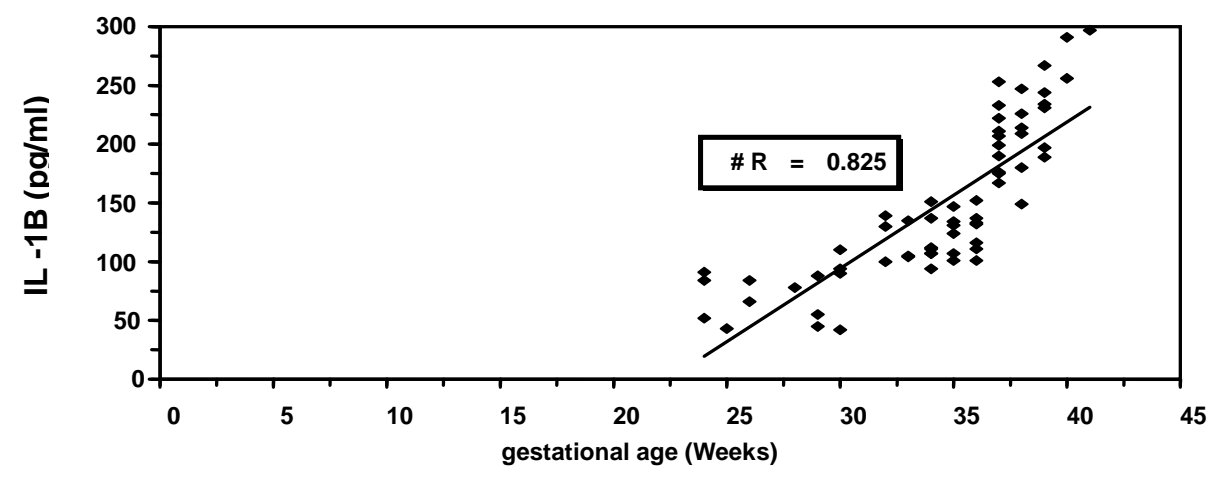

Fig. ( 6) : The correlation between IL- 1 B and gestational age inSpontaneous Delivery Group .

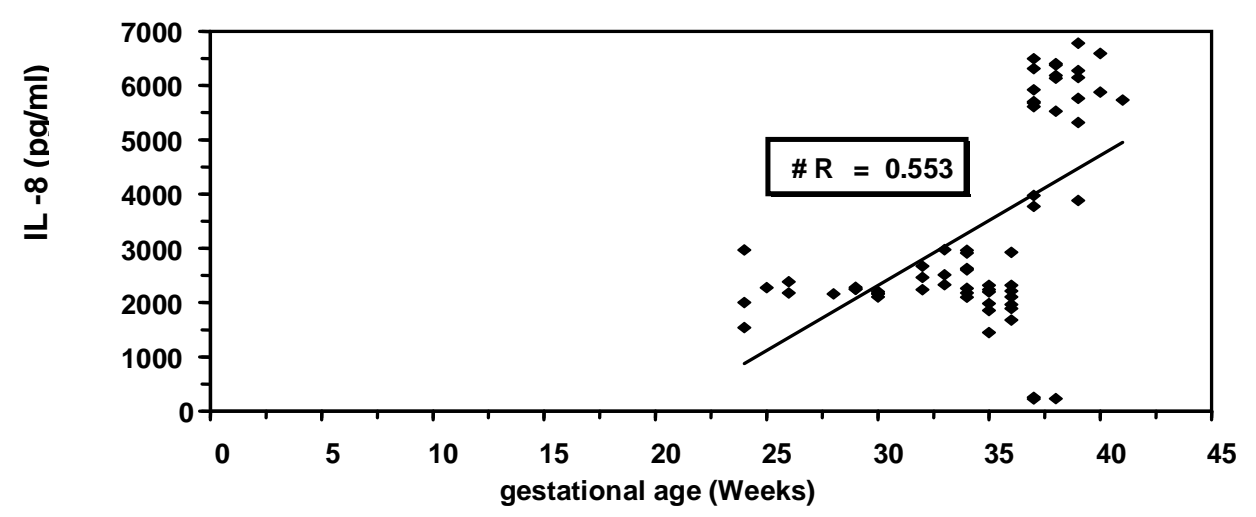

Fig. ( 7 ) : The correlation between IL-8 and gestational age in Spontaneous Delivery Group .

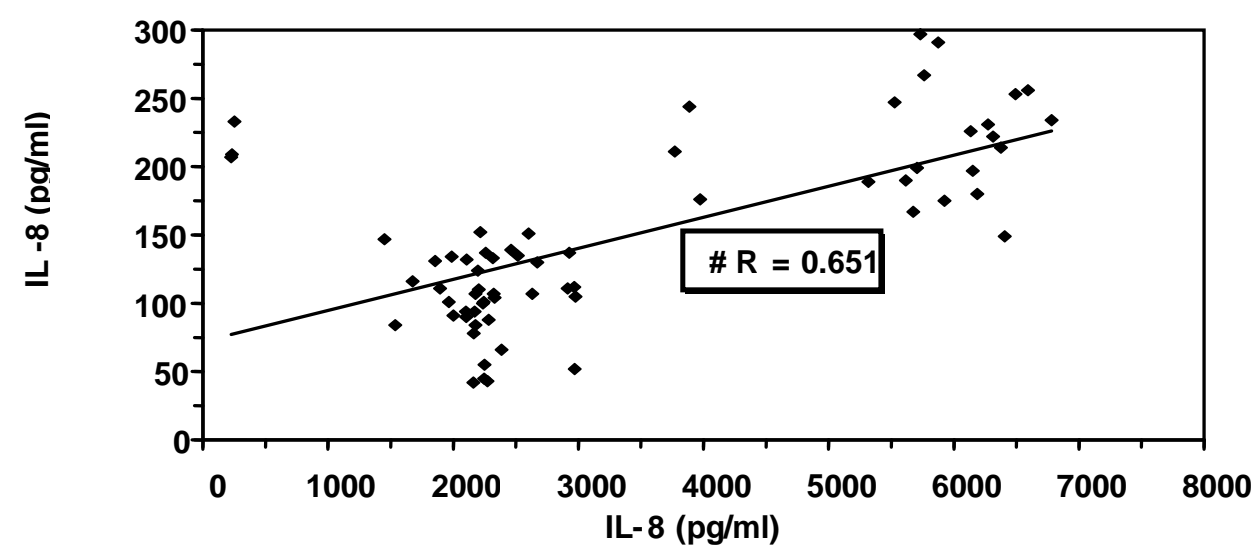

Fig. ( 8 ): The correlation between IL- 1 B and IL- 8 in Spontaneous Delivery Group. 
Table (2): The values of positive and negative cervicovaginal fetal fibronectin at preterm and full term of gestation in spontaneous labor and not in labor groups.

\begin{tabular}{|c|c|c|c|}
\hline \multicolumn{4}{|c|}{ GROUP IN SPONTANEOUS LABOR } \\
\hline & Fetal fibronectin $>0.05 \mu \mathrm{g} / \mathrm{ml}$ & Fetal fibronectin $<0.05 \mu \mathrm{g} / \mathrm{ml}$ & total \\
\hline Preterm <37 weeks & $35(87.5 \%)$ & $5(12.5 \%)$ & 40 \\
\hline Full term > 37 weeks & $22(88.0 \%)$ & $3(12.0 \%)$ & 25 \\
\hline & 57 & 8 & 65 \\
\hline \multicolumn{4}{|c|}{ GROUP NOT IN LABOR } \\
\hline & Fetal fibronectin $<0.05 \mu \mathrm{g} / \mathrm{ml}$ & Fetal fibronectin $>0.05 \mu \mathrm{g} / \mathrm{ml}$ & total \\
\hline Preterm $<37$ weeks & $36(90.0 \%)$ & $4(10.0 \%)$ & 40 \\
\hline Full term > 37 weeks & $23(92.0 \%)$ & $2(8.0 \%)$ & 25 \\
\hline & 59 & 6 & 65 \\
\hline
\end{tabular}

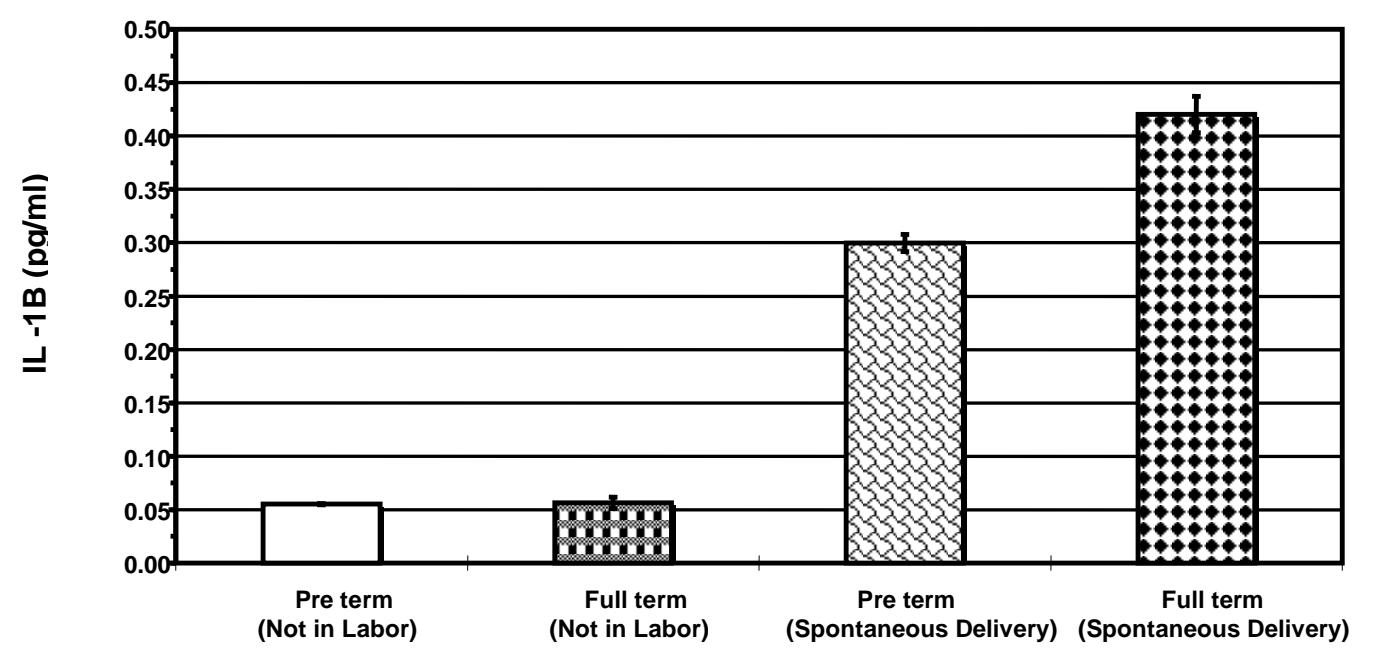

Fig. (9) : Changes in Fibronectin ( $\mu \mathrm{g} / \mathrm{ml})$ in the four studied subgroups $($ mean \pm S.E.).

\section{Discussion}

This study was one of the firsts to evaluate the combined use of fetal fibronectin and cytokines (IL-1B and IL-8) as methods of identifying women at high risk of early delivery. Mitchell et al.(1993). and Reisenberger et al. (1998), suggested that gram negative microorganisms on contact with amnion cells, have particularly high potential for stimulating prostaglandin $\mathrm{E}_{2}$, which is known to be a major inducer of uterine contractility. In this study, all cases with bacterial infection were excluded to avoid the pathophysiology of infectioninduced preterm labor.

The uterine cervix is a rigid, closed structure consisting mainly of connective tissue that retains the uterine contents during pregnancy. Between gestational weeks 37 and 41 the uterine cervix becomes soft and dilates to accommodate the passage of the fetus. If dilatation of the cervix occurs too early, the pregnancy may be terminated prematurely. Studies have suggested that IL-1B and IL-8 play 


\section{Ragab H. EL-Yamani \& Maha G. Soliman}

important roles in cervical ripening (Romero et al .,1992; Cherouny et al., 1993). IL- IB accelerates the production of collagenase in the cervix (Ito et al., 1988) and stimulates the production of elastase in cervical fibroblasts (Ito et al., 1990). IL-8, a potent chemokine for neutrophils, induces the activation and migration of cells from vessels into the surrounding uterine cervical tissue and stimulates the release of collagenase and elastase (Kanayama et al ., 1991;Osmers et al., 1992; Franz et al; 2001) in the tissue, resulting in the digestion of collagen fibers during preterm and term labor. A role for IL-8 in physiologic processes during parturition was suggested by Romero et al., (1991), who demonstrated that spontaneous labor was associated with an increased amount of IL-8 in amniotic fluid. El-Maradny et al. (1996) suggested that stretching of the lower uterine segment and the amniochorion increase IL-8 production and collagenase activity, providing further support for the role of IL-8 in human parturition. In our study cervicovaginal fluid levels of IL-I B and IL-8 increased exponentially until term in women not in labor without any evidence of cervicovaginal infection. Concentrations of these cytokines increased further during labor, which is consistent with the findings of Cox et al., (1993) for IL-lB. These observations suggest that IL-1B and IL-8 play important roles in the physiologic process of women parturition. Cervicovaginal fluid concentrations of IL-1B and IL-8 were positively correlated in women not in labor. IL-8 production by the uterine cervix is stimulated by IL-lB (Osmers et al., 1995). IL-IB and IL-8 cooperatively accelerate the production of collagenase and elastase (Ito et al., 1988, 1990). These observations indicate the presence of a cytokine network in the mechanism involving cervical softening. In our study concentrations of IL-lB and IL-8 were higher in cervicovaginal fluids from women in preterm labor than in those from women at preterm not in labor.

Detection of fetal fibronectin in cervicovaginal secretions represents a novel approach to identifying patients at high risk for preterm birth among symptomatic (Lockwood et al., 1991, Morrison et al., 1993; Paternoster et al., 2000) and asymptomatic (Lockwood et al., 1993, Nageotte et al., 1994) populations. The mechanism of the release of fetal fibronectin in these secretions remains unknown. Malak et al., (1994) reported the presence of novel zone of altered structure within the rupture site of the term spontaneously ruptured fetal membranes. The release of the fetal fibronectin from the disrupted choriodecidual interface and the dissociated membrane connective tissue that characterized this zone. The altered membrane structure may be due to decidual membrane activation that may occur as a part of a common terminal pathway in both term and preterm birth to allow separation of the lower pole of fetal membranes from the decidua of the lower uterine segment (Goldenberg et al, 1996). Inflammatory processes that may disrupt the fetal fibronectin along the choriodecidual interface and then promote further membrane degradation and uterine contractions via proteases may induce this activation and prostaglandin mediated mechanisms (Mitchell et al., 1991). At parturition, the destruction of the basement membrane results in, releasing of fetal fibronectin which seeps into the space between the decidua and the membranes and eventually finds its way to cervix and vagina. In this study we found that cervicovaginal fetal fibronectin levels were higher in women in preterm labor than in those from women at preterm not in labor and were significantly higher in women at term in labor than in women at term not in labor. Faron et al. (1998) found that the presence of fetal fibronectin in cervicovaginal secretions is associated with delivery before 34,35 or 37 weeks in both high and low risk women. Finally our findings suggest that increased levels of fetal fibronectin, IL-1B and IL-8 may be associated with both labor and the progression of cervical dilatation and that measurement of cervicovaginal fluid levels of these markers could be clinically useful in predicting the onset of labor and detecting the patients with preterm delivery. 


\section{References}

1. Adair C.D., Gunter M., Thomas G. Stovall. and Mcelroy G.(1998): Chlamydia in pregnancy: A randomized trial of azithromycin and erythromycin. Obstet Gynecol., 91:165-168.

2. Anai T., Tanaka Y., Hirota Y. and Miyakawa I. (1997): Vaginal fluid HCG levels for detecting premature rupture of membranes. Obstet. Gynecol., 89:261-264.

3. Baggiloilni M., Watz A. and Kunkel SL (1989): Neutrophil peptide interleukin-8, a novel cytokin that activates neutrophils. J Clin. Invest., 84:1045-1049.

4. Barclay C.G., Brennand J.E., Kelly R.W. and Calder A.A. (1993): Interleukin -8 production by the human cervix. Am .J. Obstet. Gynecol., 169:625-632.

5. Burrus D.R., Ernest J.M. and Veille J.C. (1995): Fetal fibronectin, interleukin -6 and C-reactive protein are useful in establishing prognostic subcategories of idiopathic preterm labor. Am.J.Obstet. Gynecol., 173:1258-1262.

6. Cherouny P.H., Pankuch G.A. and Romero, A. (1993): Neutrophil attractant / activating peptide -I / interleukin-8: association with histologic choriamnionitis, preterm delivery, and bioactive amniotic fluid leukoattractants. Am. J. Obstet. Gyecol., 169:12991303.

7. Chien P.F.W., Khan K.S., Ogston S. and Owen P. (1997): The diagnostic accuracy of cervico-vaginal fetal fibronectin in predicting preterm delivery: an overview. Br. J. Obstet Gynecol., 104: 436-444.

8. Copper R.L., Golberg R.L. and Creasy R.K. (1993): A multicenter study of preterm birth weight and gestational age-specific neonatal mortality. Am. J .Obstet. Gynecol., 168-183.

9. Cox S.M., King M.R. and Casey L.(1993): Macdonald PC: Interleukin IB- 1 alpha and prostaglandin in vaginal cervical fluids of pregnant women before and during labor. J. Clin Endocrinol .Metab.; 77:805-815.

10. Creasy R.K. (1993): Preterm birth prevention Where are we? Am. J Obstet. Gynecol.; 168: 1223 - 1230.

11. Creasy R.K. and Merkatz I.R. (1990): Prevention of preterm birth: Clinical Opinion Obstet Gynecol., 76 (1 suppl): 25-45.

12. Dinarello C.A. (1991): Interleukin -1 and interleukin 1 antagonism. Blood; 165: 969-971.

13. Dinarello, C.A. (1996): Biologic basis for interleukin - 1 in disease. Blood; 87: 2095-2147.

14. El-Maradny E., Kanayama N., Halim A., Maehara $K$ and Sumimoto K., Terao T. (1994): Interleukin-8 induces cervical ripening in rabbit. Am J Obstet Gynecol; 171:77-83.

15. El-Maradny E., Kanayama N., Halim A., Maehara K., Sumimoto K. and Terao T. (1995): The effect of inlerleukin-l in rabbit cervical ripening. Eur. J. Obstet. Gynecal. Reprod. Biol., 60:75-80.

16. El-Maradny E., Kanayama N. and Halim A., (1996): Stretching of fetal membranes increases the concentration of interleukin -8 and collagenase activity. Am. J. Obstet. Gynecol., 174:843-849.

17. Faron G., Boulvain M., Irion O., Bernard P.M. and Fraser W.D. (1998): Prediction of preterm delivery by fetal fibronectin: A Meta analysis. Obstet .Gynecol .; 92: 153-158

18. Feinberg R.F., Kliman H.J. and Lockwood, C.J. (1991): Is oncofetal fibronection trophoblastic glue for human implantation? Am. J. Pathol., 138:537-543.

19. Franz A.R., Steinbach G., Kron M. and Pohlanbt F.(2001) :Interleukin 8:a valuble tool to restrict antibiotic therapy in newborn infants. Acta. Paediatr., 90:1025-1032

20. Gibbs R.S., Romero R., Hillier S., Eschenbach B.A. and Sweet R.L. (1992): A review of premature birth and subclinical infection. Am. J. Obstet Gynecol., 166: 1515 - 1528. 
21. Goldenberg R.L., Mercer B.M., Meis P.J., Copper R.L, Das A. and McNettis D (1996): The preterm prediction study: Fetal fibronectin testing and spontaneous preterm birth. Obstet., Gynecol, 87: 643-648.

22. Gomez R., Galasso M. and Romero., (1994): Ultrasonographic examination of the uterine cervix is a better than cervical digital examination as a predictor of the likelihood of premature delivery in-patients with preterm labor and intact membranes. Am J Obstet Gynecol 162: 55-66.

23. Iams J.D., Casal D., Mc Gregor J.A, Goodwin T.M, Kreaden U.S, and Lowensohn R., (1995): Fetal Fibronectin improves the accuracy of diagnosis of preterm labor. Am .J. Obstet Gynecol, 173:141-145.

24. Ito A., Goshowaki H,. Sato T. and Mori Y. (1988): Human recombinant interleukin- 1 alpha mediated stimulation of procollagenase production and suppression of biosynthesis of tissue inhibitor of metalloproteinases in rabbit uterine cervical fibroblasts. FEBS Lett., 234: 326-330.

25. Ito A., Leppert P.C. and Mori Y. (1990): Human recombinant interleukin - $1 \&$ increases elastase -like enzyme in human uterine cervical fibroblast. Gynecol Obstet Invest., 30:239-241.

26. Kanayama K. and Terao T. (1991): The relationship between granulocyte elastase like activity of cervical mucus and cervical maturation. Acta Obstet Gynecol Scand., 70:29-34.

27. Kerise M.J. (1995): New perspectives for the effective treatment of preterm labor. Am. J. Obstet. Gynecol., 173: 618-628.

28. Langer B., Boudier E. and Schlaeder G. (1997): Cervico-vaginal fetal fibronectin: Predictive value during false labor. Acta. Obstet. Gynecol. Scand.,76: 218-221.

29. Leeson S.C., Maresh M.J.A., Martindale E.A., Mahmood T. and Muotune A (1996): Detection of fetal fibronectin as a predictor of preterm delivery in high-risk asymptomatic pregnancies. Br. J. Obstet. Gynaecol., 103:48-53.

30. Lockwood C.J., Senyei A.E., Discme M.R. Casal D. and Shah K. (1991): Fetal fibronectin in cervical and vaginal secretions as a predictor of pretem delivery. N. Eng. J. Med., 325: 669674.

31. Lockwood C.J., Wein R. and Lapinski R. (1993): The presence of cervical and vaginal fetal fibronectin in predicts preterm delivery in an innercity obstetric population. Am. J. Obstet Gynecol., 169: 798-804.

32. Lockwood C.J. (1994): Recent advances in elucidating the pathogenesis of preterm delivery, the detection of patients at risk, and preventive therapies. Curr. Opin. Obstet. Gynecol., 6:7-18.

33. Lu G.C., Goldenberg R.I., Cliuer S.P., Kreadeu U.S. and Andvews W.W.(2001) : Vaginal fetal fibonectin levels and spontaneous preterm birth in symptomatic women. Oblet. Gynecol., 97:225-228.

34. Malak T.M. and Bell S.C. (1994): Structural characteristics of term human fetal membranes (amniochorion and decidua): a novel zone of morphological alteration within the rupture site. Br. J. Obstet. Gynaecol., 101: 375-386.

35. Malak T.M., Sizmur F., Bell S.C and Taylor D.J. (1996): Fetal fibronectin in cervicovaginal secretions as a predictor of preterm birth. Br J Obstet Gynecol, 103: 648-655.

36. Mitchell M.D. (1991): Current topic: The regulation of Placental eicosanoid biosynthesis. Placenta., 12:557.

37. Mitchell M.D., Edwin S.S. and Lundin-Schiller S. (1993): Mechanism of interleukin-1B stimulation of human amnion prostaglandin biosynthesis: mediation via a novel inducible cyclooxygenase. Placenta, 14:615-625.

38. Morrison J.E., Allbert J.R., McLaughlin B.N. and Whitworth N.S. (1993): Oncofetal fibronectin inpatients with false labor as a predictor of preterm delivery. Am. J. Obstet. Gynecol., 168:538-542. 
39. Morrison J.E., Naef R.W., Botti J.J., Katz M., Belluomini J.M. and McLaughlin B.N. (1996): Prediction of spontaneous preterm birth by fetal fibronectin and uterine activity. Am. J. Obstet. Gynecol., 87: 649-655

40. Nageotte M.P., Casal D. and Senyei A.E. (1994): Fetal fibronectin in patients at increased risk for premature birth. Am. J. Obstet. Gynecol.,170:2025

41. Ness R.B. McLaughlin M.T., Heine RP. and Debra C. (1998): Fetal fibronectin as a marker to discriminate between ectopic and intrauterine pregnancies. Am. J. Obstet. Gynecol., 179:697-702.

42. Osmers R., Rath W., AdelmannGrill BC., Fittkow C., Kuloczik M., Szeverenyi M. (1992): Origin of cervical collagenase during parturition. Am J Obstet Gynecol; 166:1455-1460.

43. Osmers R., Blaser J., Kuhn W. and Tschesche H. (1995): Interleukin-8 synthesis and the onset of labor. Obstet Gynecol., 86:223-229.

44. Paternoster D.M., Pigna taro R., Stella A.; Bertoidini M. and Braeciante R. (2002): Comparative analysis of premature labor markers. Acta. Biomed. Atenea. Parmense., 71:331-336.

45. Rajabi M.R., Dean. D.D., Beydoun S. and Woessner J.F.(1988): Elevated tissue levels of collagenase during dilatation of uterine cervices in human parturition. Am .J. Obstet. Gynecol., 159:971-976

46. Reisenberger K., Egarter C., Knofler M. and Schiebel I. (1998): Cytokine and prostaglandin production by amnion cells in response to the addition of different bacteria. Am. J Obstet. Gynecol., 178:50-53.

47. Romero R., Ceska M., Avila C., Mazor M., Behnke E. and Lindley I. (1991): Neutrophil attractant /activating peptide- 1 interleukin -8 in term and preterm parturition. Am. J. Obstet. Gynecol., 165:813-820.
48. Romero R., Mazor M., Brandt F. and Sepulveda W. (1992): Interleukin - 1 alpha and interleukin-1B in preterm and term human parturition. Am. J. Reprod. Immunol., 27:117-123.

49. Steinborn A., Kuhnert M. and Halberstad E. (1996): Immunmodulating cytokines induce term and preterm labor. J. Perinat Med., 24:381390.

50. Steinborn A., Gall C.V., Hildenbrand R. Stutte H.J. and Kaufmann. M. (1998) Identification of placental cytokine-producing cells in term and preterm labor. Obstet. Gynecol., 91:329-335.

51. Tanaka Y., Narahara H., Takai N. and Yoshimatsu, J. (1998): Interleukin- $1 \mathrm{~B}$ and interleukin -8 in cervicovaginal fluid during pregnancy. Am. J. Obstet. Gyncol., 79:644-649

52. Taylor D. (1984): Low birth weight and neuro-developmental handicap. Clin. Obstet. Gynecol., 11: 525-542.

53. Trautman M.S., Dudley D.J., Edwin S.S., Collmer D, and Mitchell M.D. (1992): Amnion Cell biosynthesis of interleukin-8: Regulation by inflammatory cytokines .J. Cell. Physiol., 153:38-43.

54. Uchiyama T., Ito A., Ikesue A. Nakagawa H. and Mori Y. (1992): Chemotactic factor in the pregnant rabbit uterine cervix. Am .J. Obstet. Gynecol., 167: 1417-1422.

55. Uldbjerg N., Ulmsten U. and Ekman G. (1983): The ripening of the human uterine cervix in terms of connective tissue biochemistry. Clin. Obstet Gynecol., 26:14-26.

56. Wennerholm U.B., Holm B. and Mattsby-Baltzer M. (1997): Fetal fibronectin, endotoxin, bacterial vaginosis and cervical length as predictors of preterm birth and neonatal morbidity in twin pregnancies. Br.J. Obstet. Gyneco., 104: 1398-1404.

57. Wiqvist N. (1993): Fetal fibronectin and preterm birth. Acta. Obstet Gynecol. Scand., 72: 507-508. 


\section{تقدير مستويات الانترليوكين و الفيبرونيكتين كدلال لموعد الولادة}

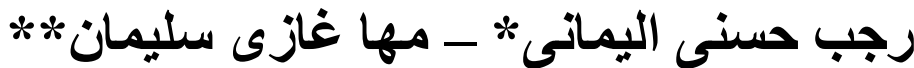

* قسم النساء و الو لادة - كلية الطب - جامعة المرقب ـ الجماهيرية العربية الليبية

$$
\begin{aligned}
& \text { العظمى }
\end{aligned}
$$

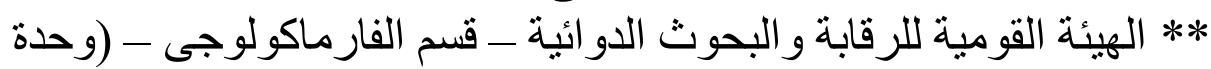

$$
\begin{aligned}
& \text { البكتريولوجى و المناعة ) }
\end{aligned}
$$

بـالر غم مـن ان منـع الو لادة المبكرة يعتبـر مـن اكبر التجديات فـى الولادة ـ فـان

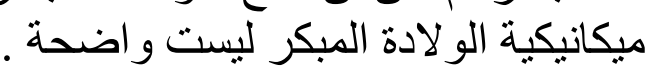

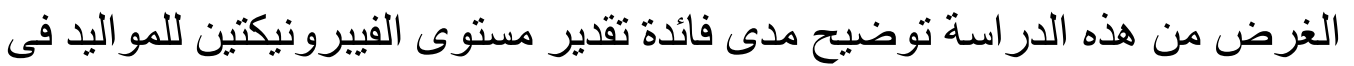

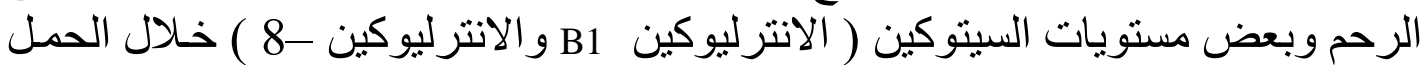

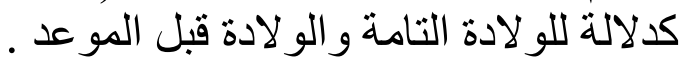

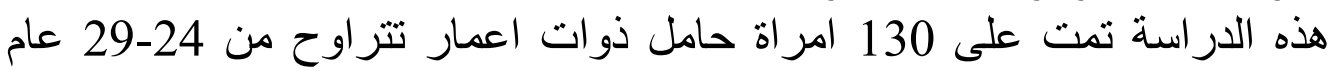

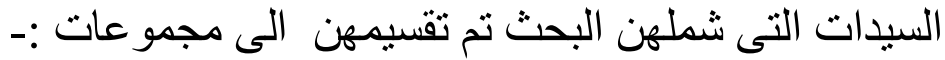

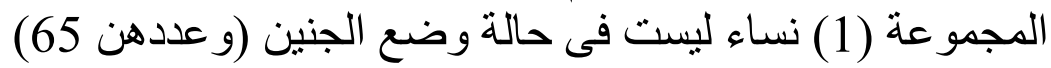

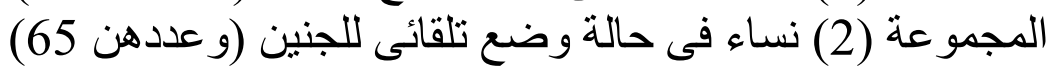

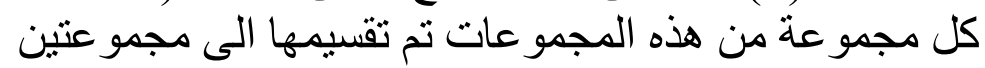

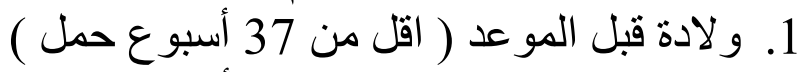

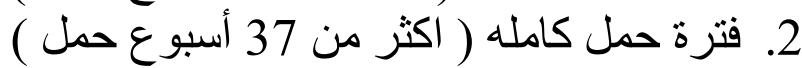

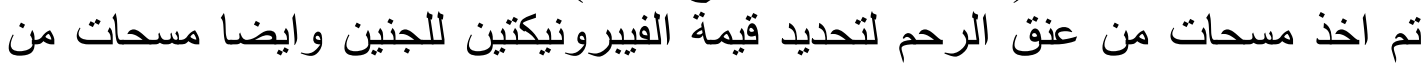

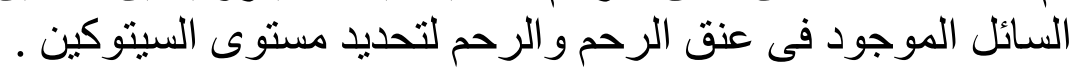

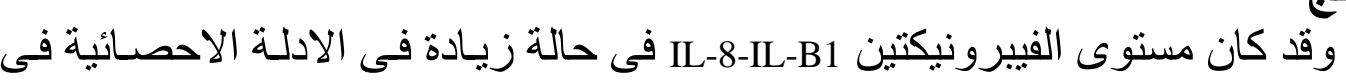
النتائج

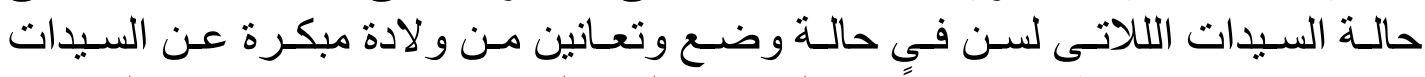

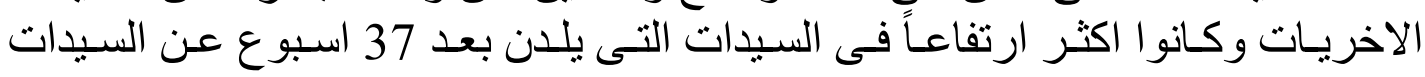

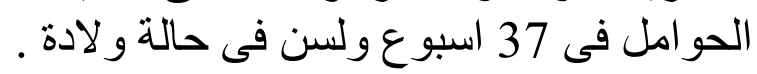

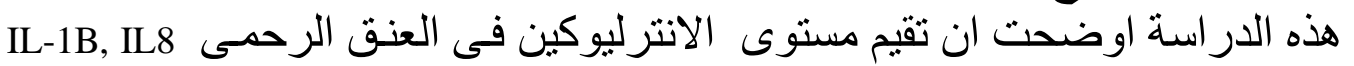

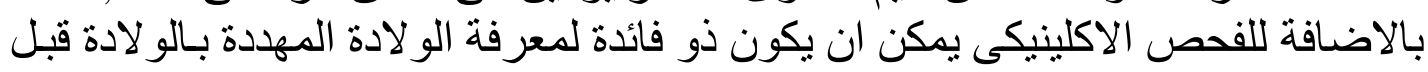

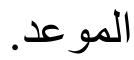

